\title{
Effect of heat shock protein 70 polymorphism on thermotolerance in Tharparkar cattle
}

\author{
Sandip Bhat ${ }^{1}$, Pushpendra Kumar ${ }^{1}$, Neeraj Kashyap ${ }^{1}$, Bharti Deshmukh ${ }^{2}$, Mahesh Shivanand Dige ${ }^{1}$, Bharat Bhushan ${ }^{1}$,
} Anuj Chauhan ${ }^{1}$, Amit Kumar ${ }^{1}$ and Gyanendra Singh ${ }^{3}$

1. Division of Animal Genetics, Indian Veterinary Research Institute, Izatnagar, Uttar Pradesh, India; 2. Department of Animal Genetics and Breeding, Govind Ballabh Pant University of Agriculture and Technology, Pantnagar, Uttarakhand, India; 3. Division of Physiology and Climatology, Indian Veterinary Research Institute, Izatnagar, Uttar Pradesh, India. Corresponding author: Sandip Bhat, e-mail: sandipivri@gmail.com,

PK: pushpendra64@gmail.com, NK: neeraj.vety@gmail.com, BD: bharti.vet@gmail.com, MSD: maheshdige@gmail.com, BB: bbhushan_ivri2003@yahoo.co.in, AC: anuj_vet99@rediffmail.com, AK: vetamitchandan07@gmail.com, GS: gyanendra@ivri.res.in

Received: 17-05-2015, Revised: 05-12-2015, Accepted: 18-12-2015, Published online: 03-02-2016

doi: 10.14202/vetworld.2016.113-117 How to cite this article: Bhat $S$, Kumar $P$, Kashyap N, Deshmukh B, Dige MS, Bhushan B, Chauhan A, Kumar A, Singh G (2016) Effect of heat shock protein 70 polymorphism on thermotolerance in Tharparkar cattle, Veterinary World 9(2): 113-117.

\begin{abstract}
Aim: Out of various members of heat shock protein (HSP) superfamily which act a molecular chaperon by binding to the denaturing protein thus stabilizing them and preserving their activity, HSP70 are of major importance in thermotolerance development. Thus, present investigation aimed at a screening of HSP70 gene for polymorphisms and possible differences in thermotolerance in Tharparkar breed of cattle.
\end{abstract}

Materials and Methods: A 295 bp fragment of HSP70 gene was subjected to polymerase chain reaction-singlestrand conformation polymorphism (SSCP) followed by sequencing of different SSCP patterns in 64 Tharparkar cattle. A comparative thermotolerance of identified genotypes was analyzed using heat tolerance coefficients (HTCs) of animals for different seasons.

Results: Three SSCP patterns and consequently two alleles namely A and B were documented in one fragment of HSP70 gene. On sequencing, one single-nucleotide polymorphism with $\mathrm{G}>\mathrm{T}$ substitution was found at a position that led to a change of amino acid aspartate to tyrosine in allele A. It was found that in maintaining near normal average rectal temperature, genotype AA was superior $(\mathrm{p} \leq 0.01)$. Genotype AA, thus, was found to be most thermotolerant genotype with the highest HTC $(\mathrm{p} \leq 0.01)$.

Conclusion: The polymorphism at HSP70 is expected to be a potent determinant for heat tolerance in cattle, which may aid in selection for thermotolerance in cattle.

Keywords: cattle, heat tolerance, heat shock protein 70, polymorphism, Tharparkar.

\section{Introduction}

India is a vast country comprising different agroecological regions with diverse climate, natural vegetation resources, topography that possess almost all domesticated animal species and crops with different production systems. In a tropical country like India, temperature in the summer rises about $40-48^{\circ} \mathrm{C}$ which unquestionably is out of the comfort range of animals and causing stress. Stress represents the reaction of the body to stimuli that disturbs homeostasis, often with detrimental effects [1] which reflected in the failure to achieve genetic potential for production traits resulting a negative influence on the growth [2], lactation $[3,4]$, reproductive performance $[5,6]$, and immune functions $[2,7]$ of the animals.

Copyright: Bhat, et al. Open Access. This article is distributed under the terms of the Creative Commons Attribution 4.0 International License (http://creativecommons.org/licenses/by/4.0/), which permits unrestricted use, distribution, and reproduction in any medium, provided you give appropriate credit to the original author(s) and the source, provide a link to the Creative Commons license, and indicate if changes were made. The Creative Commons Public Domain Dedication waiver (http://creativecommons.org/ publicdomain/zero/1.0/) applies to the data made available in this article, unless otherwise stated.
When a cell experiences environmental stress, it stops or at least slows down most of its original functions, such as transport processes, DNA, RNA and protein synthesis. However, there are proteins which preferentially expressed under these, restrictive conditions like slick hair gene [8], ATP1A1 [9,10], ATP1B2 [11] and heat shock proteins (HSPs). HSPs are highly conserved proteins activated by numerous physiological and physical stressors [12]. HSP acts as molecular chaperones by participating in the assembly of proteins without being part of the final protein structure [13] and confer thermotolerance and the ability of the cell to survive injury and oxidative stress [14] by reducing the accumulation of damaged or abnormal polypeptides within cells [15]. They perform a crucial role in intracellular transport by maintaining proteins in an inactive form and preventing protein degradation [16]. HSP70 is an essential molecular chaperone of primary importance to all mammalian cells. Extensive research indicates that HSP70 can act as a molecular chaperone and protects the cell against exposures to lethal heat shock, which is capable of denaturing proteins. HSP70 along with HSP27 and HSP90 proteins is predominantly anti-apoptotic [17] 
and the cytoprotective functions of HSP70 have been established in many organs such as intestine [18], brain [19] and kidney [20] as well as in embryo [21].

During their separate evolution from Bos taurus, zebu cattle (Bos indicus) has acquired genes that confer thermotolerance at the physiological and cellular levels. Once specific genes responsible for thermotolerance in zebu have been identified or mapped, breeding strategies such as marker assisted selection can be applied to further the exploitation of the zebu genotype for cattle production systems [22]. Adamowicz et al. [23] found a novel single-nucleotide polymorphism (SNP) in the 3' untranslated region of HSP70 gene, whereas Li et al. [24] found five novel mutations in HSP70 gene and reported that some of the genotypes confer better thermotolerance. Lamb et al. [25] found 8 SNPs in HSP70 gene of different cattle breeds and deduced that 5 of them were related to Brahman ancestry.

Therefore, in the present study, polymorphisms of HSP70 were explored for thermotolerance effects in Tharparkar cattle.

\section{Materials and Methods}

\section{Ethical approval}

The experiment was conducted following the code of ethics for animal experimentation with prior approval by the Institute's Animal Ethics Committee constituted as per the article number 13 of the CPCSEA rules laid down by Government of India.

\section{Experimental animals}

A total of 64 Tharparkar cattle (one of the best indigenous dairy breed) from Cattle and Buffalo Farm, LPM section, Indian Veterinary Research Institute, Izatnagar, Uttar Pradesh were randomly selected for the present investigation. The study was conducted in strict accordance with the code of ethics for animal experimentation and animals were handled gently and carefully.

Rectal temperature (RT) and respiration rate (RR) of each animal were taken twice in a day (10 am and $2 \mathrm{pm}$ ) for 3 successive days in each season, i.e., winter (January), spring (March), and summer (May).

\section{Genotyping of animals}

About $10 \mathrm{ml}$ of blood from jugular vein was collected from each animal under sterile conditions and stored at $-20^{\circ} \mathrm{C}$ until use. Genomic DNA was isolated from blood as per standard phenol: chloroform extraction protocol [26].

Primers were designed based on sequence of HSP70 gene to amplify two separate fragments of
HSP70 gene of length $220 \mathrm{bp}$ and $295 \mathrm{bp}$ at initial coding region (Table-1). Amplification of HSP70 gene was carried out using polymerase chain reaction (PCR) reaction mixture of $25 \mu 1$ containing $2.5 \mu 1 \times 10$ Taq buffer, $2 \mu 1$ of $25 \mathrm{mM} \mathrm{MgCl}, 1 \mu 1$ of $50 \mathrm{ng}$ genomic DNA, $1 \mu 1$ of each of $10 \mathrm{pM} / \mu 1$ forward and reverse primers, $0.8 \mu \mathrm{l}$ of $10 \mathrm{mM}$ deoxynucleotides mix, $1 \mu \mathrm{l}$ of $1 \mathrm{U} / \mu \mathrm{l} \mathrm{Taq}$ DNA polymerase and final dilution was made by adding $15.7 \mu 1$ of nuclease free water. PCR was done with $5 \mathrm{~min}$ of initial denaturation at $95^{\circ} \mathrm{C}$ followed by 30 cycles of $60 \mathrm{~s}$ denaturation at $95^{\circ} \mathrm{C}, 45 \mathrm{~s}$ annealing at $65^{\circ} \mathrm{C}$ for Fragment I and at $60^{\circ} \mathrm{C}$ for Fragment II, $60 \mathrm{~s}$ extension at $72^{\circ} \mathrm{C}$ and $10 \mathrm{~min}$ of final extension at $72^{\circ} \mathrm{C}$. Horizontal submarine $(1.5 \% \mathrm{w} / \mathrm{v})$ agarose gel electrophoresis was used to check the amplification.

Polymorphism was screened using PCR-single strand conformation polymorphism (SSCP) technique. About $5 \mu 1$ of PCR product was taken with $15 \mu 1$ formamide dye $(95 \% \mathrm{v} / \mathrm{v}$ formamide, $4 \% \mathrm{v} / \mathrm{v} 0.5 \mathrm{M}$ ethylenediaminetetraacetic acid [EDTA], $0.025 \% \mathrm{w} / \mathrm{v}$ bromophenol blue and $0.025 \% \mathrm{w} / \mathrm{v}$ xylene cyanol) and mixed properly followed by denaturation at $95^{\circ} \mathrm{C}$ for $10 \mathrm{~min}$ then snap chilling on ice for $15 \mathrm{~min}$. The mixture was loaded on $12 \%$ polyacrylamide gel (acrylamide/bis-acrylamide 29:1, w/w). Electrophoresis was carried out using $\times 1$ tris-borate-EDTA $(45 \mathrm{mM}$ tris-borate $/ 1 \mathrm{mM}$ EDTA) at $130 \mathrm{~V}$ for $20 \mathrm{~h}$ at $4^{\circ} \mathrm{C}$ temperature. Band patterns were detected by silver staining [27]. The bands representing different SSCP patterns were purified and sequenced for all the genotypes by the Sanger's sequencing method from both forward and reverse directions for each sample.

\section{Temperature humidity index and heat tolerance coefficient}

Temperature humidity index (THI) was recorded by taking daily mean temperature as the average of maximum and minimum temperatures of the day for 3 successive days of each season, i.e., winter, spring and summer using dry and wet bulb thermometer to record dry and wet bulb air temperatures 4 times a day ( $8 \mathrm{am}, 11 \mathrm{am}, 2 \mathrm{pm}$ and $5 \mathrm{pm}$ ) for 3 consecutive days for each season under study then THI was derived for each day and expressed as:

$$
\mathrm{THI}=0.72\left(\mathrm{~T}_{\mathrm{w}}+\mathrm{T}_{\mathrm{D}}\right)+40.6[28],
$$

Where, $\mathrm{T}_{\mathrm{w}}$ is wet bulb air temperature $\left({ }^{\circ} \mathrm{C}\right)$ and $\mathrm{T}_{\mathrm{D}}$ is dry bulb air temperature $\left({ }^{\circ} \mathrm{C}\right)$.

Heat tolerance parameters RT and RR were recorded at $10 \mathrm{am}$ and $2 \mathrm{pm}$ for 3 successive days of

Table-1: Primer sequences used to amplify HSP70 gene of Tharparkar cattle.

\begin{tabular}{lcccc}
\hline Fragment & & Primers & Amplicon size & Position on HSPA1A mRNA \\
\hline I & Forward & 5'-AAACATGGCTATCGGCATCGACCT-3' & 295 & $181-475$ \\
& Reverse & 5'-AGGCTTGTCTCCGTCGTTGATGA-3' & & $474-693$ \\
II & Forward & 5'-CTAAGGTGCAGGTGAGCTACAAAG-3' & 220 & \\
& Reverse & 5'-TTGATGATCCTCAGCACGTTCAGC-3' & & \\
\hline
\end{tabular}

HSP70 $=$ Heat shock protein 70

Veterinary World, EISSN: 2231-0916 
each season. The average RT (ART) and average RR (ARR) were calculated as the mean of twice daily recording data. To assess heat adaptability of animals, heat tolerance coefficient (HTC) was calculated [29], with the equation:

$$
\mathrm{HTC}=100-10(\text { ART }-38.3) \text {, }
$$

Where, ART is average rectal temperature of 10 am and 2 pm of 3 consecutive days for each season and 38.3 is normal RT of cattle $\left({ }^{\circ} \mathrm{C}\right)$.

\section{Statistical analysis}

The effect of season and genotype was analyzed on different RTs (10 am, 2 pm and average), HTC and ARR for the population under study. A comparison of least square means was performed by GLM procedure of SAS 9.3 using the following model as $Y_{\mathrm{ijkl}}=\mu+$ $\mathrm{S}_{\mathrm{i}}+\mathrm{G}_{\mathrm{j}}+\mathrm{e}_{\mathrm{ijk}}$, where $\mathrm{Y}_{\mathrm{ijk}}$ is the observation of the trait; $\mu$ is overall mean; $S_{i}$ is effect of $i^{\text {th }}$ season; $G_{j}$ is fixed effect of $j^{\text {th }}$ genotype and $\mathrm{e}_{\mathrm{ijk}}$ is random error.

\section{Results and Discussion}

Tharparkar was found polymorphic for PCRSSCP of amplified Fragment I (295 bp) of HSP70 gene and three SSCP-patterns were evident on PCR-SSCP (Figure-1). Nucleotide sequencing followed by alignment of three SSCP-patterns revealed a substitution of $\mathrm{G}>\mathrm{T}$ and $\mathrm{G}>\mathrm{C}$ at $149^{\text {th }}$ position of the amplicon with respect to B. taurus HSP70 gene (NM_174550.1), leading to two allele $\mathrm{A}$ with nucleotide $\overline{\mathrm{T}}$ and allele B with nucleotide C (Figure-2) at $149^{\text {th }}$ position of Fragment I with 0.5078 and 0.4922 allele frequencies, respectively in Tharparkar population. The allele

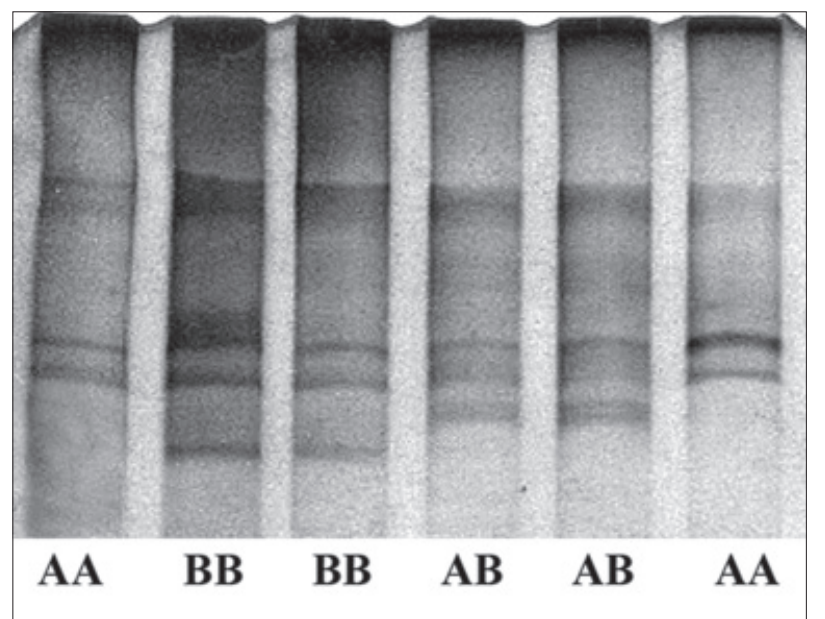

Figure-1: Polymerase chain reaction-single-strand conformation polymorphism patterns of Fragment I of heat shock protein 70 gene.
A and B were submitted to NCBI with accession no JX966362 and JX966363, respectively. Frequencies of three genotypes were 0.3281 for AA 0.3594 for AB and 0.3125 for BB. The SNP found was novel and has not yet been reported in any of the SNP databases for cattle. The SNP resulted in amino acid changes in A allele from aspartate to tyrosine whereas, in B allele aspartate changes to histidine with respect to $B$. taurus HSP70 protein. While the Fragment II (220 bp) of the HSP70 gene showed monomorphic SSCP pattern (Figure-3), which was further confirmed by random sample sequencing and submitted to NCBI with accession no JX966360.

During the study, the average THI values were the highest for summer (84.34) followed by spring (68.25) and lowest for winter (52.72) season. The THI in summer season exceeded 72 , i.e., the reported threshold value of THI for dairy cattle, thus imposing heat stress. Least squares mean for genotype and season were significantly different $(\mathrm{p} \leq 0.01)$ for $10 \mathrm{am}$ RT, 2 pm RT, ART and HTC (Table-2). In summer, the highest values for 10 am RT, 2 pm RT, ART and ARR while the lowest value for HTC in summer indicated heat stress. There were significant differences $(\mathrm{p} \leq 0.01)$ between genotypes with AA genotype holding lowest values for 10 am RT, $2 \mathrm{pm}$ RT and ART in pooled seasons as well as in summer alone. Genotype AA held the highest value for HTC, followed by genotype $A B$ $(96.58 \pm 0.27)$ and BB (95.22 \pm 0.29$)$. A significant genotype effect in ARR was recorded having highest value for genotype $\mathrm{BB}$ followed by $\mathrm{AB}$ while genotype AA accounted for the least ARR.

The effects of heat in the organisms are related to hyperthermia and consequent impairment of tissue and organ functions through reduction on blood flow [30]. The important physiological response of cattle to heat stress includes raised RRs and RT [31] that was evident in Tharparkar. In this study, the allelic variants of HSP70 gene were found to be associated with heat tolerability of the Tharparkar cattle. Li et al. [24], Basiricò et al. [32] and Xiong et al. [33] also found mutations at different locus in HSP70 gene in Holstein cattle that showed differences in thermotolerance. However, they were at different locus; they support the findings of the present study that the gene is important for thermotolerance in cattle. Further indigenous cattle like Tharparkar which have already been said to have thermotolerance, it has been confirmed by the present study that they may have more variations conferring thermotolerance that may provide a chance of improving these breeds for higher thermo-tolerability.

$$
\begin{aligned}
& \text { CIICACCGAZACCGAGCGGCICATCGGGXATGCGGCCAAG MajoItY } \\
& 130 \quad 140 \quad 150 \quad 160 \\
& 121 \text { CIICACCGATACCGAGCGGCICATCGGGGATGCGGCCA AG HSP } 70 \text { BOS TAURUS } \\
& 121 \text { C T TCACCGATACCGAGCGGCTCATCGGGIATGCGGCCA A G HSP FRAG I ALLELE A } \\
& 121 \text { CITCACCGATACCGAGCGGCTCATCGGGCATGCGGC CA A G HSP FRAG I ALLELE B }
\end{aligned}
$$

Figure-2: Sequence alignment of Fragment I of heat shock protein 70 gene. 
Table-2: Effects of genotype and season on heat tolerance parameters on Tharparkar cattle.

\begin{tabular}{lccccc}
\hline Effects & $\mathbf{1 0} \mathbf{~ a m ~ R T ~}$ & $\mathbf{2 ~} \mathbf{~ m ~} \mathbf{R T}$ & ART & HTC & RR \\
\hline Season & & & & & \\
$\quad$ Winter & $38.17^{\mathrm{a}} \pm 0.03$ & $38.62^{\mathrm{a}} \pm 0.03$ & $38.39^{\mathrm{a}} \pm 0.03$ & $99.05^{\mathrm{a}} \pm 0.29$ & $14.88^{\mathrm{a}} \pm 0.09$ \\
$\quad$ Spring & $38.77^{\mathrm{b}} \pm 0.03$ & $38.85^{\mathrm{b}} \pm 0.03$ & $38.61^{\mathrm{b}} \pm 0.03$ & $96.84^{\mathrm{b}} \pm 0.28$ & $15.53^{\mathrm{b}} \pm 0.11$ \\
Summer & $38.64^{\mathrm{c}} \pm 0.03$ & $39.13^{\mathrm{c}} \pm 0.03$ & $38.89^{\mathrm{c}} \pm 0.03$ & $94.13^{\mathrm{c}} \pm 0.29$ & $17.3^{\mathrm{c}} \pm 0.11$ \\
Genotype for all seasons & & & & \\
AA & $38.23^{\mathrm{a}} \pm 0.03$ & $38.72^{\mathrm{a}} \pm 0.03$ & $38.48^{\mathrm{a}} \pm 0.03$ & $98.22^{\mathrm{a}} \pm 0.28$ & $15.31^{\mathrm{a}} \pm 0.08$ \\
AB & $38.39^{\mathrm{b}} \pm 0.03$ & $38.88^{\mathrm{b}} \pm 0.03$ & $38.64^{\mathrm{b}} \pm 0.03$ & $96.58^{\mathrm{b}} \pm 0.27$ & $15.91^{\mathrm{b}} \pm 0.07$ \\
BB & $38.55^{\mathrm{c}} \pm 0.03$ & $38.99^{\mathrm{a}} \pm 0.03$ & $38.78^{\mathrm{c}} \pm 0.03$ & $95.22^{\mathrm{c}} \pm 0.29$ & $16.48^{\mathrm{c}} \pm 0.07$ \\
Genotype for summer & & & & & \\
AA & $38.52^{\mathrm{a}} \pm 0.04$ & $38.97^{\mathrm{a}} \pm 0.05$ & $38.74^{\mathrm{a}} \pm 0.04$ & $95.56^{\mathrm{a}} \pm 0.41$ & $16.74^{\mathrm{a}} \pm 0.22$ \\
AB & $38.63^{\mathrm{b}} \pm 0.04$ & $39.14^{\mathrm{b}} \pm 0.04$ & $38.88^{\mathrm{b}} \pm 0.04$ & $94.15^{\mathrm{b}} \pm 0.39$ & $17.24^{\mathrm{b}} \pm 0.21$ \\
BB & $38.78^{\mathrm{c}} \pm 0.04$ & $39.29^{\mathrm{c}} \pm 0.05$ & $39.03^{\mathrm{c}} \pm 0.04$ & $92.67^{\mathrm{c}} \pm 0.42$ & $17.93^{\mathrm{c}} \pm 0.23$ \\
\hline
\end{tabular}

Different superscript in same column within season and genotype indicate significant differences $(p \leq 0.01)$. HTC $=$ Heat tolerance coefficient, $R T=$ Rectal temperature, $R R=$ Respiration rate, $A R T=$ Average rectal temperature, $A R R=A v e r a g e$ respiration rate

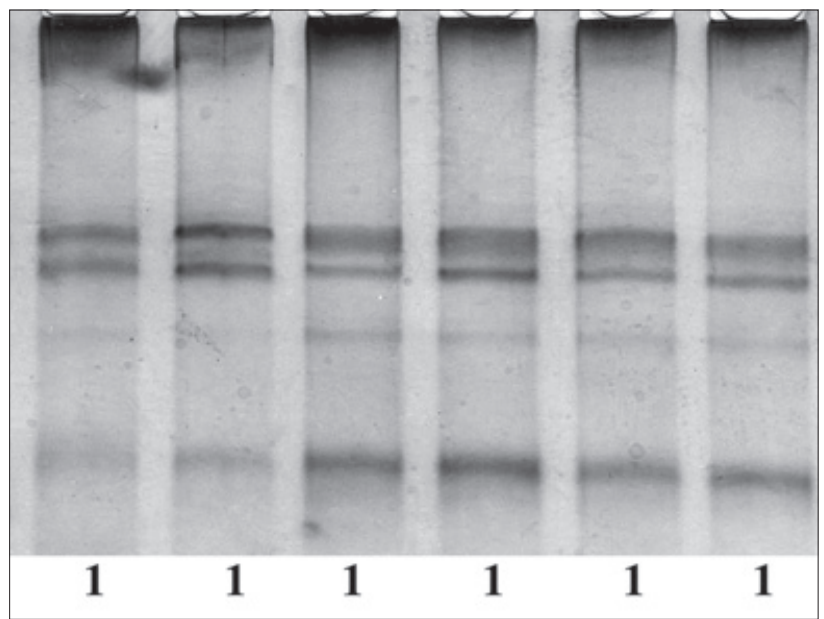

Figure-3: Polymerase chain reaction-single-strand conformation polymorphism patterns of Fragment II of heat shock protein 70 gene.

\section{Conclusion}

Heat stress is one of the critical factors among various environmental stressors that impede profitable livestock rearing. The higher values of RT and RR in summer indicate heat stress in Tharparkar population. Present investigation establishes strong association between the HSP70 polymorphism and heat tolerability parameters, with the allele A having a positive effect on heat tolerance and genotype AA being superior in heat tolerance. Thus, this locus can be used as an indicator of thermotolerance in cattle, though further validation may be needed in other cattle breeds and in a larger population before its practical application.

\section{Authors' Contributions}

SB: Research was done by this author as the part of his master's degree thesis dissertation. PK: Designed the study and supervised the research as major advisor. NK, BD and MSD: Worked and collaborated in the lab work and compilation of the results as well as the manuscript. AC and AK: Provided valuable suggestions regarding the design of the experiment and analysis of the data collected during research. BB: advised in all aspects of the work and shared lab facilities. GS: As an expert of animal physiology and climatology, provided valuable suggestions and implementable ideas of recording physiological and climatological parameters. All authors read and approved the final manuscript.

\section{Acknowledgments}

The authors are thankful to the Director of the institute and in charge of cattle and buffalo farm for providing necessary facilities and personnel to carry out this work.

\section{Competing Interests} interests.

The authors declare that they have no competing

\section{References}

1. David, K., Murgo, A.J. and Faith, R.E. (1990) Effects of stress on the immune system. Immunol. Today, 11(10): 348.

2. Tao, S., Monteiro, A., Thompson, I., Hayen, M. and Dahl, G. (2012) Effect of late-gestation maternal heat stress on growth and immune function of dairy calves. J. Dairy Sci., 95(12): 7128-7136.

3. Boonkum, W., Misztal, I., Duangjinda, M., Pattarajinda, V., Tumwasorn, S. and Sanpote, J. (2011) Genetic effects of heat stress on milk yield of Thai Holstein crossbreds. J. Dairy Sci., 94(1): 487-492.

4. Bernabucci, U., Biffani, S., Buggiotti, L., Vitali, A., Lacetera, N. and Nardone, A. (2014) The effects of heat stress in Italian Holstein dairy cattle. J. Dairy Sci., 97(1): 471-486.

5. Avendaño-Reyes, L., Fuquay, J.W., Moore, R.B., Liu, Z., Clark, B.L. and Vierhout, C. (2010) Relationship between accumulated heat stress during the dry period, body condition score, and reproduction parameters of Holstein cows in tropical conditions. Trop. Anim. Health Prod., 42(2): 265-273.

6. Ferreira, R., Ayres, H., Chiaratti, M., Ferraz, M., Araújo, A., Rodrigues, C., Watanabe, Y., Vireque, A., Joaquim, D. and Smith, L. (2011) The low fertility of repeat-breeder cows during summer heat stress is related to a low oocyte competence to develop into blastocysts. J. Dairy Sci., 94(5): 2383-2392.

7. Carroll, J., Burdick, N., Chase, C., Coleman, S. and Spiers, D. (2012) Influence of environmental temperature on the physiological, endocrine, and immune responses 
in livestock exposed to a provocative immune challenge. Domest. Anim. Endocrinol., 43(2): 146-153.

8. Dikmen, S., Alava, E., Pontes, E., Fear, J.M., Dikmen, B.Y., Olson, T.A. and Hansen, P.J. (2008) Differences in thermoregulatory ability between slick-haired and wild-type lactating Holstein cows in response to acute heat stress. J. Dairy Sci., 91(9): 3395-3402.

9. Liu, Y.X., Li, D.Q., Li, H.X., Zhou, X. and Wang, G.L. (2011) A novel SNP of the ATP1A1 gene is associated with heat tolerance traits in dairy cows. Mol. Biol. Rep., 38(1): 83-88.

10. Kashyap, N., Kumar, P., Deshmukh, B., Dige, M.S., Sarkar, M., Kumar, A., Chauhan, A. and Singh, G. (2014) Influence of ambient temperature and humidity on ATP I Al gene expression in Tharparkar and Vrindavani cattle. Indian J. Anim. Res., 48(6): 541-544.

11. Wang, Z., Wang, G., Huang, J., Li, Q., Wang, C. and Zhong, J. (2011) Novel SNPs in the ATP1B2 gene and their associations with milk yield, milk composition and heat-resistance traits in Chinese Holstein cows. Mol. Biol. Rep., 38(3): 1749-1755

12. Yang, M., Tan, H., Yang, Q.L., Wang, F., Yao, H.L., Wei, Q.Y., Tanguay, R.M. and Wu, T.C. (2006) Association of HSP70 polymorphisms with risk of noise-induced hearing loss in Chinese automobile workers. Cell Stress Chaperon, 11: 233-239.

13. Ellis, R.J. (1987) Proteins as molecular chaperones. Nat. Insects, 328: 378-379.

14. Lindquist, S. and Craig, D. (1988) The heat shock proteins. Annu. Rev. Genet., 22: 631-677.

15. Parsell, D.A. and Lindquist, S. (1993) The function of heat-shock proteins in stress tolerance: Degradation and reactivation of damaged proteins. Annu. Rev. Genet., 27: 437-496.

16. Neuer, A., Spandorfer, S.D., Giraldo, P., Dieterle, S., Rosenwaks, Z. and Witkin, S.S. (2000) The role of heat shock proteins in reproduction. Eur. Soc. Hum. Reprod. Embryol., 6(2): 149-159.

17. Garrido, C., Gurbuxani, S., Ravagnan, L. and Kroemer, G. (2001) Heat shock proteins: Endogenous modulators of apoptotic cell death. Biochem. Biophys. Res. Commun., 286: 433-442.

18. Tsuruma, T., Yaagihashi, A., Matsuno, T., Zou, X.N. and Hirata, K. (1996) The heat shock protein 70 family reduces ischemia reperfusion injury in small intestine. Trans. Process, 28: 2629-2630.

19. Yenari, M.A., Gffard, R.G., Sapolsky, R.N. and Steinberg, G.K. (1999) The neuroprotective potential of heat shock protein 70. Mol. Med. Today, 5: 525-531.
20. Beck, F., Neuhafer, W. and Nuller, E. (2000) Molecular chaperones in the kidney: Distribution, putative roles and regulation. Am. J. Physiol., 279: F203-F215.

21. Luft, J.E. and Disc, D.J. (1999) HSP 70 expression and function during embryogenesis. Cell Stress Chaperon, 43: 162-170.

22. Hansen, P.J. (2004) Physiological and cellular adaptations of zebu cattle to thermal stress. Anim. Reprod. Sci., 82: 349-360.

23. Adamowicz, T., Pers, E. and Lechniak, D. (2005) A new SNP in the 3' -UTR of the HSP 70-1 gene in Bos taurus and Bos indicus. Biochem. Genet., 43: 623-627.

24. Li, Q., Han, J., Du, F., Ju, Z., Huang, J., Wang, J., Li, R., Wang, C. and Zhong, J. (2011) Novel SNPs in HSP70A1A gene and the association of polymorphisms with thermo tolerance traits and tissue specific expression in Chinese Holstein cattle. Mol. Biol. Rep., 38(4): 2657-2663.

25. Lamb, M., Okimoto, R., Broun, M. and Rosenkranes, C., Jr. (2007) Associations between cattle breed and heat shock protein 70 gene. Res. Ser., 545: 205-206.

26. Green, M.R. and Sambrook, J. (2012) Molecular Cloning: A Laboratory Manual. Cold Spring Harbor, New York, USA.

27. Bassam, B.J., Caetano-Anollés, G. and Gresshoff, P.M. (1991) Fast and sensitive silver staining of DNA in polyacrylamide gels. Anal. Biochem., 196(1): 80-83.

28. McDowell, R.E., Hooven, N.W. and Camoens, J.K. (1976) Effect of climate on performance of Holsteins in first lactation. J. Dairy Sci., 59(5): 965-971.

29. Rhoad, A.O. (1944) The Iberia heat tolerance test for cattle. Trop. Agric., 21(9): 162-164.

30. Kregel, K.C. (2002) Invited review: Heat shock proteins: Modifying factors in physiological stress responses and acquired thermotolerance. J. Appl. Physiol., 92(5): 2177-2186

31. Omar, E.A., Kirrella, A.K., Fawzy, S.A. and El-Keraby, F. (1996) Effect of water spray followed by forced ventilation on some physiological status and milk production of post-calving Friesian cows. Alex. J. Agric. Res., 41: 71-81.

32. Basiricò, L., Morera, P., Primi, V., Lacetera, N., Nardone, A. and Bernabucci, U. (2011) Cellular thermotolerance is associated with heat shock protein 70.1 genetic polymorphisms in Holstein lactating cows. Cell Stress Chaperon, 16(4): 441-448.

33. Xiong, Q., Chai, J., Xiong, H., Li, W., Huang, T., Liu, Y., Suo, X., Zhang, N., Li, X. and Jiang, S. (2013) Association analysis of HSP70A1A haplotypes with heat tolerance in Chinese Holstein cattle. Cell Stress Chaperon, 18(6): 711-718

\section{$* * * * * * * *$}

